DOI: $10.17805 /$ trudy.2017.1.9

\title{
МЕЖДУНАРОДНАЯ НАУЧНО-ПРАКТИЧЕСКАЯ КОНФЕРЕНЦИЯ «СОЦИАЛЬНАЯ СПРАВЕДЛИВОСТЬ И ГУМАНИЗМ В СОВРЕМЕННОМ ГОСУДАРСТВЕ И ПРАВЕ»
}

\author{
T. А. Сошникова \\ Московский гуманитарный университет
}

Аннотация: В статье представлен обзор работы Международной научнопрактической конференции «Социальная справедливость и гуманизм в современном государстве и праве», которая прошла в Московском гуманитарном университете 20 февраля 2017 г.

Ключевые слова: конференция; обзор; социальная справедливость; гуманизм; юриспруденция; Московский гуманитарный университет

\section{INTERNATIONAL SCIENTIFIC AND PRACTICAL CONFERENCE "SOCIAL JUSTICE AND HUMANISM IN MODERN STATE AND LAW"}

\author{
T. A. Soshnikova \\ Moscow University for the Humanities
}

Abstract: The article provides an overview of work at the international scientific and practical conference "Social Justice and Humanism in Modern State and Law", which was held at Moscow University for the Humanities on 20th February 2017.

Keywords: conference; overview; social justice; humanism; jurisprudence; Moscow University for the Humanities

20 февраля 2017 г. в Московском гуманитарном университете состоялась Международная научно-практическая конференция «Социальная справедливость и гуманизм в современном государстве и праве», организованная юридическим факультетом.

Конференция была посвящена Всемирному дню социальной справедливости, который был объявлен 26 ноября 2007 г. Генеральной Ассамблеей ООН в резолюции № A/RES/62/10. OOH предложила государствамучастникам проводить мероприятия в интересах общественного развития 
и отмечать 20 февраля как праздничный день с целью увеличения усилий в искоренении нищеты, обеспечении занятости, достойного труда, гендерного равноправия, благосостояния окружающих.

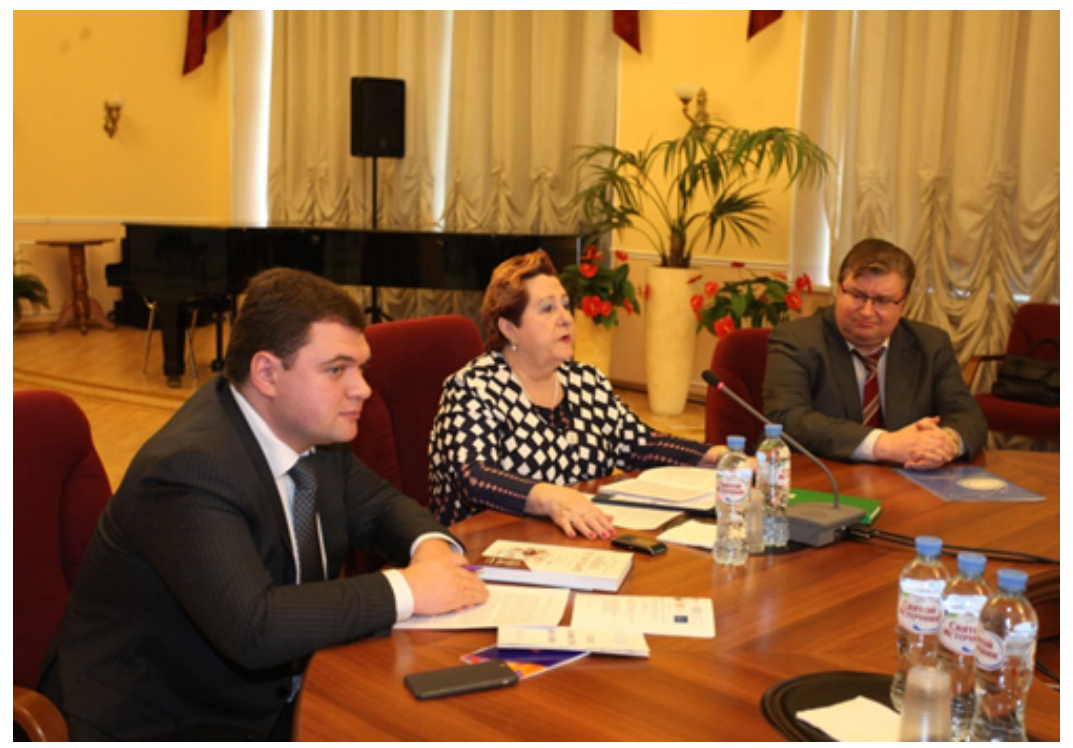

Ежегодно 20 февраля во многих странах мира проводятся просветительские лекции, семинары, конференции, на которых обсуждаются насущные проблемы социальной сферы. Рассматриваются предложения по совершенствованию законодательства, программы о трудоустройстве, пенсионном обеспечении. Активисты общественных организаций обращают внимание чиновников на актуальные вопросы социальной сферы.

Московский гуманитарный университет также уже девятый раз, с 2009 г., проводит научные конференции, на которых обсуждаются проблемы обеспечения социальной справедливости в трудовых и социальнообеспечительных отношениях, в судебной практике, в управлении государством и в бизнесе. Конференции, организуемые юридическим факультетом, постоянно проходят при большом участии представителей профессиональных общественных организаций международного и национального уровня, ведущих вузов и научных учреждений страны.

Для подготовки и проведения конференции приказом ректора университета был создан организационный комитет, возглавила который заведующая кафедрой гражданского процесса и социальных отраслей права, доктор юридических наук, профессор, академик Центральной Европейской академии науки, литературы и искусства (Сорбонна, Париж) Т.А.Сошникова. Она и была ведущей на конференции.

От имени ректората университета участников конференции приветствовала проректор Московского гуманитарного университета по науке, доктор педагогических наук, профессор Л. В. Романюк. Она обратила внимание собравшихся на идеи гуманизма в современном государстве и праве, которые тесно связаны с социальной справедливостью. В современных условиях неустойчивой экономики, сложных политических событий, когда перед человечеством стоит проблема выживания, должно меняться отношение к самому человеку и к миру, в котором он живёт. 
Философское осмысление возрастающей роли человеческого фактора на новом этапе истории требует нового способа взаимодействия с этим миром, поиска нетрадиционных путей выхода из кризисных ситуаций. В этой связи приоритетными становятся идеи гуманизма, которые рассматривают человека как высшую ценность, а его благо как критерий оценки деятельности органов госу-

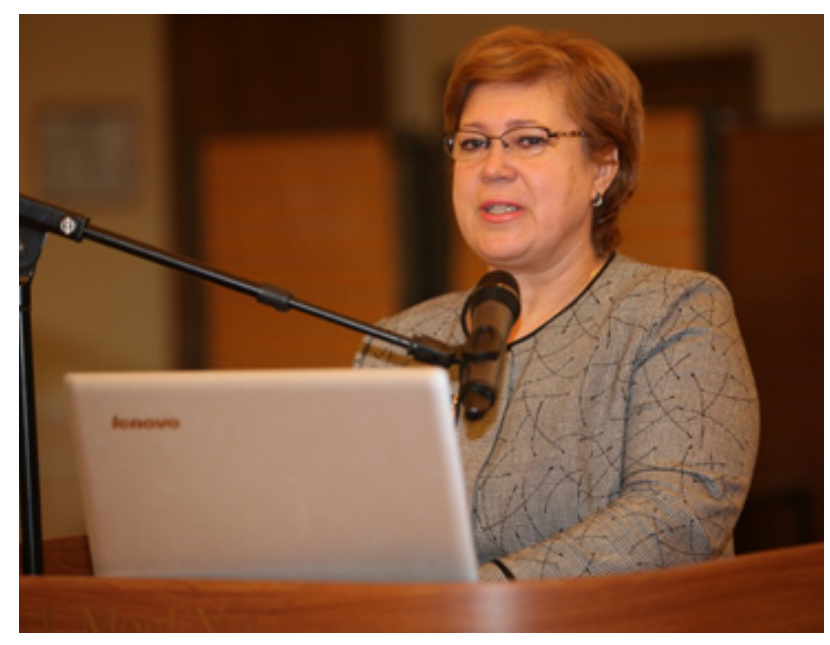
дарства, эффективности правовых установлений, человеческих отношений.

От имени юридического факультета участников конференции приветствовал кандидат юридических наук, декан юридического факультета МосГУ Е. А. Карпов.

Всего в конференции приняли участие около 100 человек - представители науки и образования Московского гуманитарного университета, Института государства и права РАН, Института законодательства и сравнительного правоведения при Правительстве РФ, Дипломатической академии МИД РФ, Академии Генеральной прокуратуры РФ, Московского государственного педагогического университета, РГУ нефти и газа имени И. М. Губкина, Украинского национального государственного университета и других вузов.

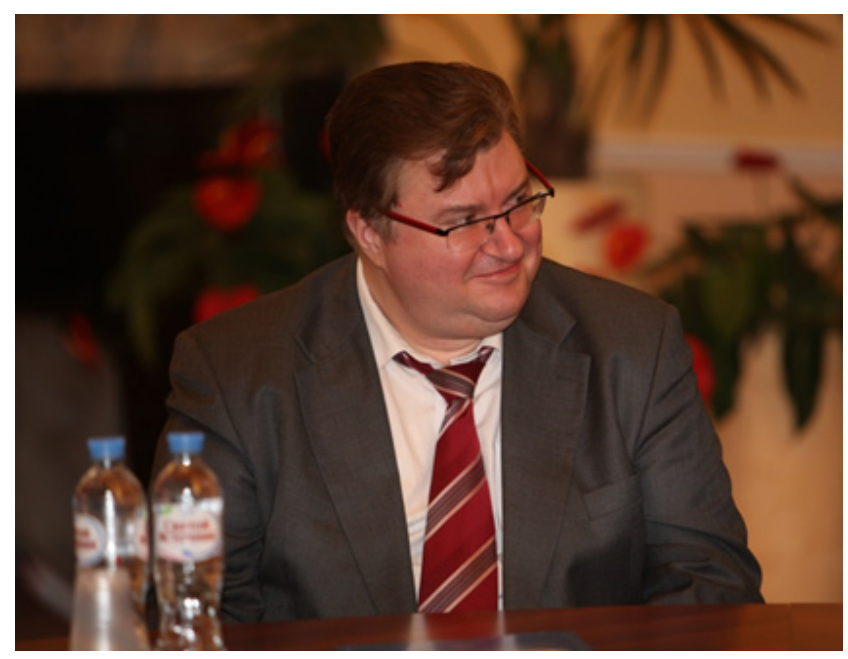

В конференции принял участие заместитель директора Информационного центра ООН, кандидат юридических наук В. С. Павинский, который выступил с докладом на тему «Организация объединенных наций и социальная справедливость». Арбитражный управляющий, первый заместитель Председателя Союза юристов Москвы М. В. Вильховский выступил с научным сообщением на тему «Права и статус работника в процедуре банкротства».

Член Исполкома координационного совета Международного союза юристов, член Президиума Союза юристов Москвы, Председатель Московского общества трудового права и права социального обеспечения, доктор юридических наук, профессор Московского государственного 
юридического университета им. О. Е. Кутафина (МГЮА) К. Д. Крылов выступил перед участниками конференции с научным сообщением на тему «Социально-правовые устремления Февральской революции 1917 года».

Директор Центра межнационального сотрудничества, кандидат физико-математических наук А. А. Айрапетян выступил с научным сообщением на тему «От социального партнёрства к социальной справедливости». Президент Ассоциации юридических вузов, главный научный сотрудник ИСПИ РАН, профессор Московского университета им. С. Ю. Витте, заслуженный деятель науки Российской Федерации, доктор юридических наук, профессор С.Н.Бабурин представил научное сообщение на тему: «Духовный смысл правовых трансформаций современ-

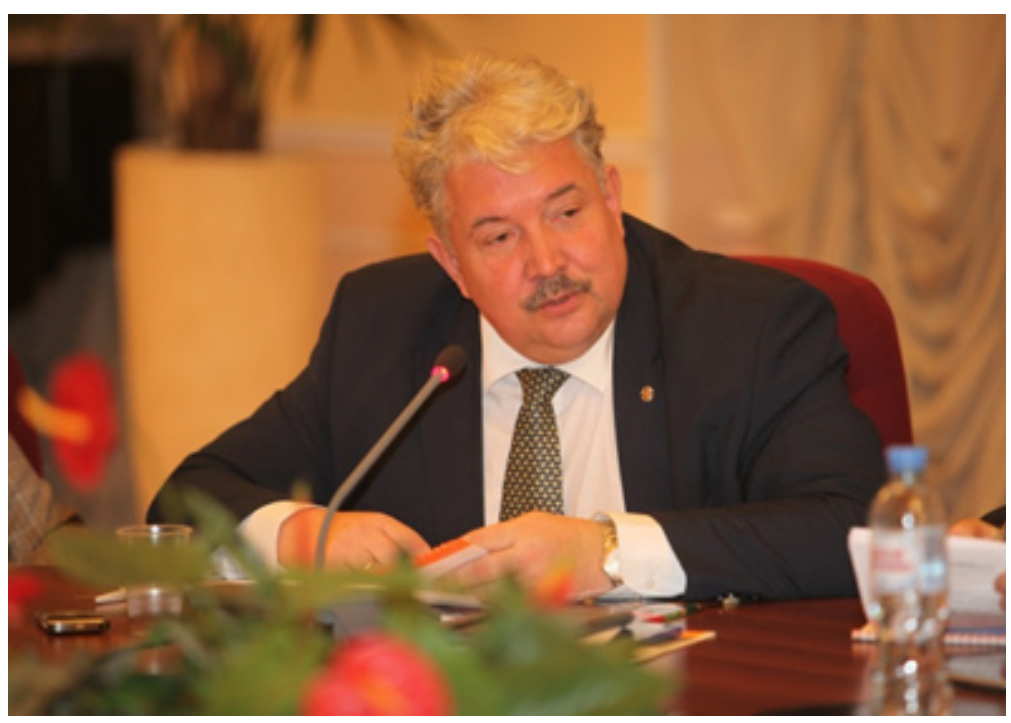
ного гуманизма».

С очень интересным, взвешенным научным сообщением на тему «Гуманизм и противоречие социальной справедливости и несправедливости» выступил кандидат философских наук, доцент кафедры общественных дисциплин Украинского национального государственного университета В. В. Терещук. Он рассказал собравшимся о положении в Украине и проблемах несправедливости, с которыми сталкиваются граждане этого государства.

Кроме пленарного заседания работа конференции проходила в трех секциях: «Социальная справедливость в трудовом праве и праве социального обеспечения», «Правовые индикаторы социальной справедливости в современном государстве и праве» и молодежная секция. Очное и заочное участие в заседании молодежной секции приняли 26 человек - студенты, магистранты и аспиранты Академии Генеральной прокуратуры, МГПУ, Академии труда и социальных отношений и других вузов. Из них 19 человек - это представители магистратуры и студенты юридического факультета МосГУ.

Дата поступления: 24.02.2017 г. 
Сошникова Тамара Аркадьевна - доктор юридических наук, профессор, заведующая кафедрой гражданского процесса и социальных отраслей права юридического факультета Московского гуманитарного университета. Адрес: 111395, Россия, г. Москва, ул. Юности, д. 5. Тел.: +7 (499) 374-72-37. Эл. адрес: soshnikova.ta@mail.ru

Soshnikova Tamara Arkadievna, Doctor of Law, Professor, Head of Department of Civil Procedure and Social Branches of Law, Faculty of Law, Moscow University for the Humanities. Postal address: 5 Yunosti St., Moscow, Russian Federation 111395. Tel: +7 (499) 374-72-37. E-mail: soshnikova.ta@ mail.ru

\section{Для цитирования:}

Сошникова Т. А. Международная научно-практическая конференция «Социальная справедливость и гуманизм в современном государстве и праве» [Электронный ресурс] // Научные труды Московского гуманитарного университета. 2017, № 1. URL: http://journals.mosgu.ru/trudy/article/view/400 (дата обращения: дд.мм.гг.). DOI: 10.17805/trudy.2017.1.19 